Encuentro №. 98, 68, 2014

\title{
Contratos civiles y mercantiles
}

Jesús Juseth Herrera Espinoza y Jairo José Guzmán García

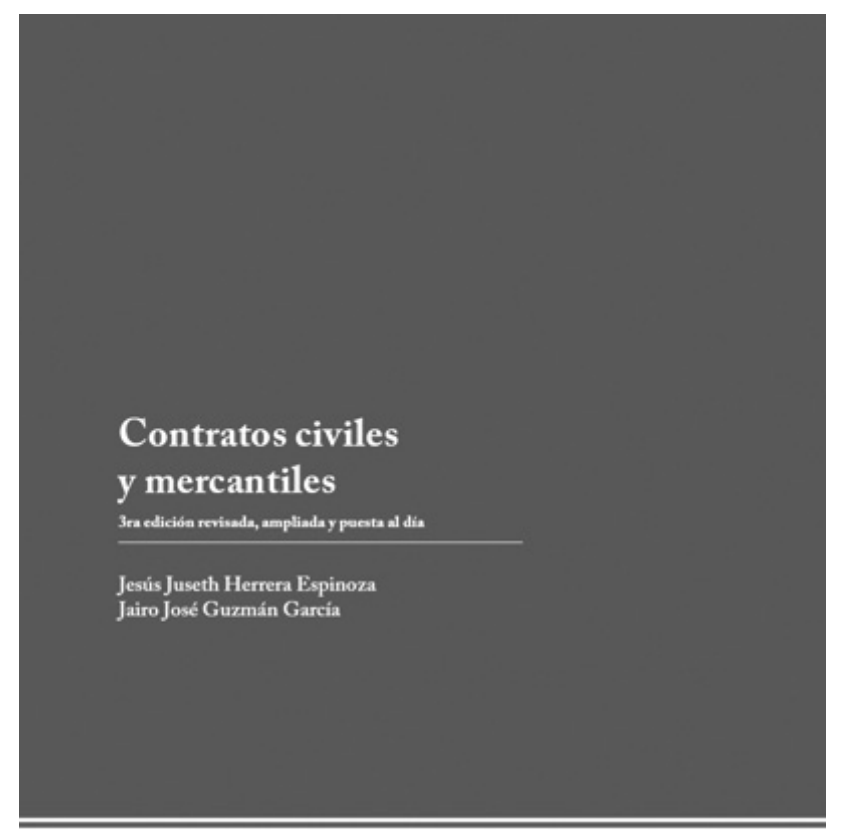

Colección đe Manuales

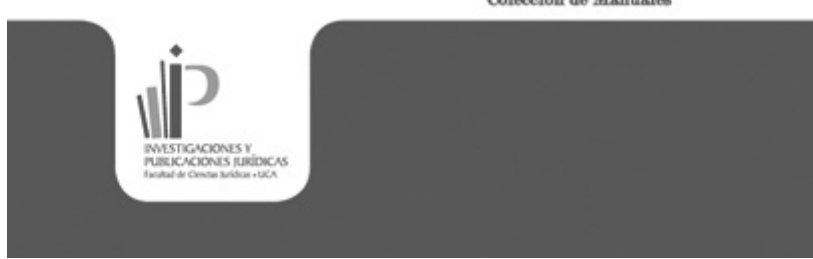

En la tercera edición de "Contratos civiles y mercantiles" los autores han pretendido poner al día la fenomenología contractual tanto en su teoría general como en el desarrollo de los particulares contratos contenidos en los Códigos Civil y Mercantil. En dicha obra se han ajustado, ampliado y mejorado temas que incorporan las nuevas meditaciones que sobre la doctrina se han realizado, ajustándola a su realidad y a la cada vez más cambiante práctica negocial globalizada. 